\title{
DEVELOPMENTS OF CARTOGRAPHY AND GEODESY IN ALBANIA (CONTRIBUTION OF PROF. SPIRO BOÇI IN PRACTICAL ALBANIAN GEODESY AND CARTOGRAPHY)
}

\author{
Pal NIKOLLI (1) ${ }^{1}$, Bashkim IDRIZI ${ }^{2,3 *}$, Ismail KABASHI ${ }^{2,4}$ \\ ${ }^{1}$ Department of Geography, University of Tirana, Tirana, Albania \\ ${ }^{2}$ Department of Geodesy, University of Prishtina "Hasan Prishtina", Prishtina, Kosova \\ ${ }^{3}$ South-East European Research Institute on Geo Sciences, Skopje, North Macedonia \\ ${ }^{4}$ ANGST Vermessung, Vienna, Austria
}

Received 10 July 2020; accepted 29 October 2021

\begin{abstract}
Name of Prof. Dr Spiro Boçi is known in the Albanian academic and scientific world, both inside and outside Albania, for his valuable contributions in the field of cartography, especially practical cartography and geodesy. With the experience of a passionate researcher, prof. Spiro Boçi has left a mark on Albanian scientific thought. He has a balance of over 40 years of extensive and successful research, publishing and pedagogical activity.

The legacy of prof. Spiros is diverse and reflects his broad interests. Scientific and pedagogical work of prof. Spiros will serve today's and tomorrow's generations and be a guide for them. Even today, Prof. Spiro Boçi continues to write and contribute successfully to the development of the science of cartography and geodesy.

In this paper an attempt is made to analyze the activity of Prof. Spiro Boçi in the field of practical cartography and geodesy and especially in the application of cartographic and geodetic methods in studying the movement of the Albanian Adriatic coastline.
\end{abstract}

Keywords: Spiro Boçi, Albania, Albanian cartography, Albanian geodesy, Adriatic coastline, dynamic of coastline.

\section{Introduction}

Prof. Spiro Boçi was born on September 28, 1932 in Leskovik. In 1953 he graduated from the Polytechnic "November 7" in Tirana. During the years 1953-1954 he worked in the former reclamation company Levan (Fier) where he implemented the works for the irrigation canal LevanFier. Then, during the years 1954-1956 he worked in the former geological enterprise in Tirana for the construction of geodetic bases in the sector of Kuçova and Patos, for the design of their topographic plans and for the design of topographic plans for the chrome areas of Bulqiza and of Kam-Tropoja and for the copper areas of Kurbnesh (Mirditë) etc.

In the period 1956-1961 he studied geodesy-cartography at the Faculty of Geodesy of the Polytechnic Institute of Warsaw (Poland) and in 1962 he defended with a "excellent" result the diploma in the Department of Geodesy of the Polytechnic University of Tirana.
From 1962 to 1994 he was a lecturer (doc) at the Faculty of Civil Engineering of the Polytechnic University of Tirana, in the Department of Geodesy. During these years he has been distinguished for a very rich pedagogical and scientific activity. He has given lectures on General Geodesy, Cartography, Geodetic Compensation and Agricultural Systems. He has published university texts, study articles, scientific studies, various references in Albanian and foreign journals. He has led various degrees and doctorates in the field of geodesy and cartography. Prof. Boçi has been an active member in all scientific activities organized in Albania, but also in those organized abroad.

Today it is authored by over 20 university textbooks (Geodesy, Exercises on General Geodesy, Geodetic Accounts, Geodesy Manual, High Geodesy, Agricultural Systems, Geodetic Calculations 2, Knowledge on Cartography, Topography, Topography, Art), over 50 study articles, a large amount of references and announcements inside and outside Albania, etc.

*Corresponding author. E-mail: bashkim.idrizi@yahoo.com 


\section{Original contribution to practical cartography and applied geodesy}

The study that has an extraordinary value and that serves as a basis for all engineering designs in the coastal area of the Albanian Adriatic is the one entitled "Topographic study of the dynamics of the coastline from Vjosa to Buna”, with which Prof. Spiro Boçi received the scientific degree "Doctor" in 1981. In fact, this study Prof. Boçi had undertaken it since 1966, for which he had published an article entitled "Study of the movement of the coastline from a topographic point of view" in the scientific journal of the University of Tirana "Bulletin of Natural Sciences". Then the studies and analyzes on the movement of the Albanian Adriatic coastline, carried out by Prof. Boçi, have been continuous and have served as a basis for almost all other types of studies in the coastal area.

The main purpose of the studies of prof. Boçi, has been and is to give a current and perspective view of the dynamics of the Adriatic Sea coastline that wet the shores of Albania. For this purpose, Prof. Boçi used cartographic data (including a period from 1870) and other existing official data, new data created by field measurements and observations, data from aerial photographs and satellite images, and so on. Through a rational organization and deep cartographic and statistical processing of these data, Prof. Boçi has reached important conclusions regarding the movement of the Albanian Adriatic coastline, accurately defining the areas in the process of erosion, in the process of accumulation and in equilibrium; determining the intensity of erosion and accumulation, surfaces accumulated and eroded over the years; the volume of solid materials transported by rivers and accumulated in coastal areas, etc.

For the first time, with traditional methods (since automatic methods had not yet begun to be applied), Prof. Boçi explored new methods of unifying cartographic materials, which were on a scale and in different projections, referring to different initial meridians and having different contents. They were compiled by various foreign and Albanian cartographic institutions.

The study of coastal erosion is a very complex task, and for this prof. Spiro Boçi had to deepen his knowledge not only in cartography, geodesy, hydrology, etc., but also in GIS/Remote Sensing statistics. The rigorous determination of this phenomenon has forced the various scientific and administrative institutions of the country to determine the directions of conservation of the coast and especially the beaches from erosion and to take appropriate measures.

Prof. Spiro Boçi has used for the first time the socalled "equilibrium points", from which the differentiation of the sectors that are in accumulation and those that are subject to erosion is the cause. Also, for the first time, Professor Boçi found and rigorously analyzed the direct dependence of the change of the Albanian Adriatic coastline on the amount of solid inflows brought by the rivers Buna, Drini, Mati, Shkumbini, Semani and Vjosa at sea, by the surface of the catchment basins of these rivers and their geological composition. He has been able to successfully combine the cartographic method with the geodetic, sedimentological, hydrogeological, etc., to point out the quantitative and qualitative changes of the coastline, the morphological transformations and the tendency of its change in the future.

In the realization of models on the prediction of the position of the coastline, prof. Boçi has taken into account the current average rate of accumulation and abrasion, human interventions in the coastal area, human interventions in river beds, natural tendencies to avoid their estuaries, port engineering constructions, increasing pressure on the territory as a result of overcrowding. etc.

Important is the fact that the accuracy of determining the position of the coastline, prof. Boçi has increased it by studying topographic maps obtained at considerable time intervals and using methods of direct field measurements against specific objects (bunkers, buildings, etc.) or based on state geodetic networks.

Of particular importance, prof. Boçi has devoted himself to the evolution of the Albanian Adriatic coastline in the Holocene and the historical period. Through the processing of cartographic materials and other data, he has been able to reconstruct the position of riverbeds in the western lowlands, the displacement of their estuaries and the formation of deltas along the coast.

\section{The dynamics of Albanian Adriatic coastline according to the Prof. Spiro Boçi}

The Albanian coastline has a total length of about 380 $\mathrm{km}$ (excluding the internal shore of coastal lagoons), with about $284 \mathrm{~km}$ stretching along the Adriatic Sea and the remaining $96 \mathrm{~km}$ facing the Ionian Sea. The Albanian coastline consists of sandy beaches for $70 \%$ of its total, most of them facing the Adriatic Sea. The Albanian Adriatic coastline has an intensive change and continuously modifying its shape (Boçi, 1981) and consist of abrasion zones and accumulation zones. Accumulative coastlines are extended at plain areas. Sandy beaches and dunes are main elements of these areas. Lagoons of Narta, Karavasta and Kune-Vaini are located in plain area of the littoral. These lagoons are formed in some sea bays, which are closed by solid sediments transported by rivers to the sea. Erosive coastlines are extended in the hilly base of some capes. Neotectonics development at the present has caused submergence of two sectors to the accumulative areas.

The dynamics of the development of this coast are subject to very special and complicated laws. The discharge of continental solid materials into the sea plays an important role in the dynamics of Adriatic coastline (Boçi, 1994). Albanian rivers discharge into the sea at an annual rate of 41.27 cubic kilomettres, which corresponds to an average flow of 1308 cubic metres per second (Simeoni et al., 1997). This intensive discharge is realised over rather a short distance of 110 kilometres (the mouth of the Vjosa Buna). 
The Adriatic coastline advancement has been made through formation of the coastal river delta cordons, which isolated coastal fragments, turning them into lagoons, marshes and wamps.

In general, coastal morphological features and coastline extension are similar for the river mouths of Vjosa, Seman and Shkumbin. The maximum displacement distance of the Seman river mouth reaches about $33 \mathrm{~km}$; at the Vjosa river it is $20 \mathrm{~km}$ while at all other rivers this value is $9-15 \mathrm{~km}$.

The coastline between the mouth of the Buna and the Viluni Lagoon was characterized in the first part of the present century by an accumulation tendency. It was advancing rapidly up to 1937 and more slowly till 1968 (Boçi, 1994). Between the 1970s and 1990s accumulation rates became increasingly smaller and in the last decade coastal erosion started along the southern lobe of the Buna Delta (between 1.5 and $2.0 \mathrm{~m} /$ year), at the island of Franc Josef and on the beaches along Viluni Lagoon, where the present coastline position is clearly further inland than that surveyed in 1918 by the Austrian Geographical Institute (Boçi, 1994).

Evidence is the presence of old rivers beds in the form of abandoned meanders; the river Drin being the most characteristic. Typical also are the old river beds of the Seman, Vjosa and Shkumbin, which formed the major part of this lowland, especially after the fifteenth and sixteenth centuries. During this period the coastline constantly advanced westward to its present position, evidenced by the presence of lagoons, swamps and abandoned meandres in the form of a wide belt along its eastern side. Obviously, in this evolution, along with accumulation, there has also been erosion activity in the opposite sectors of the river mouth displacement, e.g., along the Capes of Rodon, Bishti Palles, Cape of Turra and Treporte (Boçi, 2018).

Shuisky (1985) for example believes that the cliffs of Cape Rodoni are retreating at an average speed of $0.2 \mathrm{~m} /$ year, while Boçi (1994) proposes 0.3-0.5 m/year.

The largest natural river mouth displacement is in the Drin river, about $36 \mathrm{~km}$ in length. The last natural displacement of this river to the northwest occurred during 1859, leaving until 1963, about 20 percent of the river flow to Lezha. The big reduction of solid flow of the Drini river after 1970 (the major part of the Drin river solid load was interrupted by reservoir construction at Vau Dejes, Koman, Fierze etc), directly influenced development of coastal erosion along the coastal zone on both sides of estuary (Boçi, 1994).

The Mat river estuary, (resulted from the construction of hydroelectric power stations at Uleza and Uraka on the Uleza Lake which trapped a large part of solid materials) moved to the south during this period also led to an increase of erosion in some beaches. Natural displacement of the Mat river after 1975-1978, was about $2.5 \mathrm{~km}$ towards Patok lagoon in the south, forming a littoral cordon and a new lagoon almost parallel to that of Patok. The coastal strip is $3 \mathrm{~km}$ long and 50 to $100 \mathrm{~m}$ wide and represents a shield against beach erosion at Patok. The erosion of $\mathrm{Pa}-$ tok Beach began in the early 1980s, caused by changes in the hydrological regime of the Ishmi, due to engineering works started as early as the 1960s. In the last centuries the Ishmi changed course on several occasions (Boçi, 1994).

Until the 90s of XX century, the whole Albanian Adriatic coastline advanced towards the sea, but in specific sectors erosion predominated with 0.3 to $20 \mathrm{~m}$ /year, except at the Seman river impact area where this value is $30 \mathrm{~m} /$ year. The deposition/erosion ratio of the Adriatic coastline, was from 2:1 to 5:1, with an average value for the last 110 years being 2.5:1 (Boçi, 1981). Every year a total land area of about 105 ha formed and nearly 42 ha eroded, resulting in an average addition of $63 \mathrm{ha} /$ year. Over the last 110 years some 2200 ha in the Albanian Adriatic lowland has been eroded, producing a coastline withdrawal of 2.5 to $3 \mathrm{~km}$ (between the rivers mouths of Shkumbin and Seman and partly between the river mouths of Seman and Vjosa) (Boçi, 1994).

The Semani also changed the position of its estuary with time, being always characterized by a number of secondary channels. The river estuary changed position six times in the last one hundred years, moving along a coastal strip of 23-25 km. Between the end of the 19'th century and the 1950s the northern channels became increasingly important (Figure 1). Thereafter, until the 1960s, the delta plain advanced towards the sea and in the 1970s the coastline reached its present position. In this period of positive migration, the accretion rate was in the order of 40-50 m/year. The coastline around the estuary has two sectors, sites of old river channels, which are unequivocally eroding. The first sector started to erode at the end of the 19'th century, with an approximate speed of about $30 \mathrm{~m}$ /year. Paskoff (1985) evaluates modern erosion rates as $15 \mathrm{~m}$ /year. Despite the fact that erosion slowed down, it is still a dominant factor at Semani beach, a popular coastal resort twenty years ago, nowadays almost disappeared. The second sector that is eroding is located $13 \mathrm{~km}$ northwards from the estuary of the Semani. Published work (Pano, 1984) relates the erosion to changes in the river estuary induced by the disastrous floods of the winters of 1962-1963. Average erosion rates calculated for the last 30 years are in the order of $35 \mathrm{~m} /$ year (Boçi, 1994), with maximum peaks of about $50 \mathrm{~m} /$ year (Pano, 1984).

The estuary of the Vjose river has been in constant accretion for the last 120 years, with maximum growth between 1918-57 (Figure 1). Later the delta started to be reworked by wave action. The estimated growth rate was in the order of $15 \mathrm{~m} /$ year for the period 1918 and 1972. Southwards of the present delta there is an area, $4 \mathrm{~km}$ long, where erosion has been taking place (average $15 \mathrm{~m} /$ year, maximum $47 \mathrm{~m}$ /year), dismantling about 1200 hectares of beach. The erosion is caused by the abandonment of one of the channels of the Vjosa, occurred progressively between 1937 and 1957. Erosion speeds have become smaller from the early 1970s onwards, in the order of $8 \mathrm{~m} /$ year (Boçi, 2002). 
Nowadays, these reports have been reversed in favor of abrasion. Thus, e.g. the beaches of Tale, Kune Vaini and Shengjin are subject to erosion. The evolution of the coastline in recent years cannot be considered completely natural, since river engineering works in the hinterland have significantly altered sediment discharge. As a result of the exploitation of rivers and the acquisition of inerts for three decades, the natural balances of river and sea relations have been disturbed. Rivers no longer discharge solid materials into the sea, and the sea has begun to invading land. The phenomenon of marine erosion and floods in the Lezha Lowland, more than tidal problems and rising levels from global warming, are problems of disturbing these balances. According to Prof. Boçi, the sea progresses on average 15-20 meters per year. Specifically, in Seman, on a $6 \mathrm{~km}$ long coastline, over the last ten years, the sea has received 200 hectares of beach, forest and land. As a result of the destruction of the rivers Erzen and Ishëm, the beach of Lalzi Bay will be invaded by the sea.

From cartographic studies it emerges that the estuary of the Erzeni, between 1918 and 1990, has progressively rotated southwards (Figure 1). This has caused a continuous erosion of the northern lobe of the delta and an accretion of the southern one at a speed of about $50 \mathrm{~m} /$ year (Boçi, 1994). For the same period Boçi (1994) indicates a total erosion of four kilometers for the coast northwards of the Erzeni mouth, while Pano (1992) considers it of six kilometers with a retreat of $5 \mathrm{~m} /$ year.

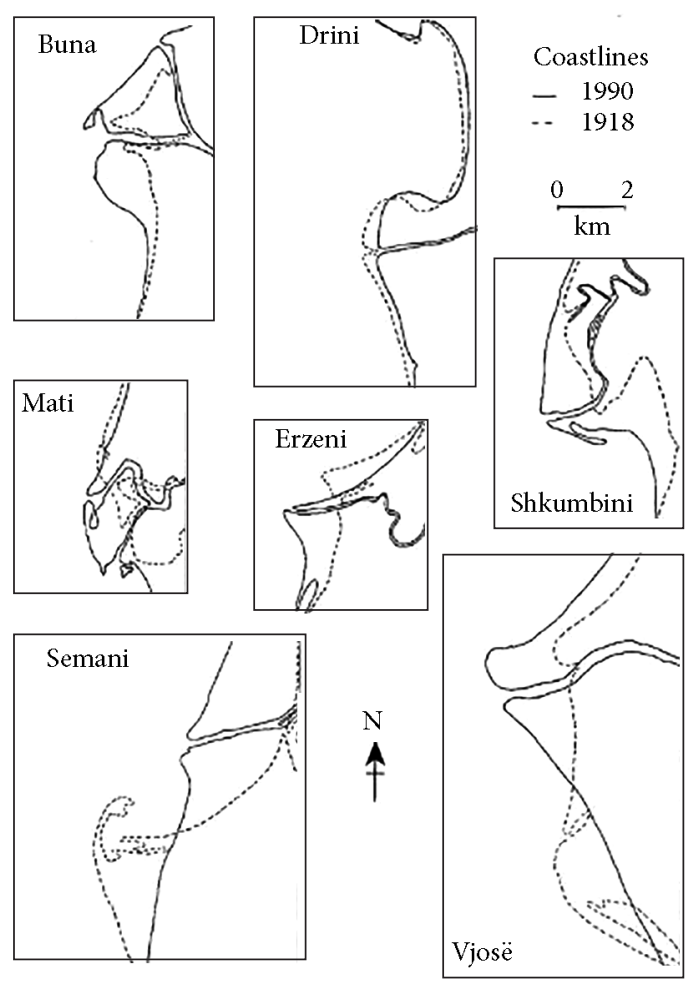

Figure 1. Coastal change at the mouth of major Albanian rivers between 1918-1990 (1918 coastline surveyed by Astrian Geographical Institute, 1990 coastline modified from Boçi, 1994)
As a result of this aggressiveness, the Buna estuary area is being destroyed and Velipoja beach has undergone major changes (Boçi, 2018).

Given the wide range of factors that shape the coastal area, but also the fact that during this century is expected to have an increase in significant values of sea level as a result of global warming, prof. Boçi concludes that many beaches and even large coastal sectors are endangered on the Albanian Adriatic coast.

For the realization of studies, prof. Boçi has compiled many maps, which are distinguished for their individuality both in terms of choosing the mathematical basis and the system of cartographic signs and the presentation of the coastal geographical environment.

\section{Conclusions}

The conclusions drawn by prof. Boçi from his studies on the dynamics of the Albanian Adriatic coastline are of special importance. The main economic and social activity of the country takes place in the coastal area of the Albanian Adriatic; we have the highest population density, thanks to the extent of most of the country's major cities and villages, including Tirana; some of the most protected areas in the country, etc. are located. Therefore, the results of the studies of prof. Boçi serve specialists in various fields such as geologists, biologists, hydrologists, geographers, territorial planners, etc., but especially serve central and local state bodies to take the necessary measures to better manage the coastal area. and its rational utilization.

The results of the studies of prof. Spiro Boçi are an important contribution to the development of the science of cartography, especially practical cartography, but also of geodesy and other related sciences.

Even today, prof. Spiro Boçi contributes tirelessly, where he has lived since 1994, to Washington (USA), constantly deepening his studies in the direction of the evolution of the Albanian Adriatic coastal area through cartographic methods and GIS / Remote sensing. He represents a European cartographer and surveyor.

\section{References}

Boçi, S. (1981). Studimi topografik i dinamikës së vijës bregdetare nga Vjosa nё Bunë [Topographic study of the dynamics of the coastline from Vjosa to Buna] [doctoral dissertation]. Faculty of Engineering, University of Tirana, Tiranë.

Boçi, S. (1994). Evoluzione e problematiche ambientali del litorale albanese. Bollettino Societa Geologica Jtaliana, 113, 7-14.

Boçi, S. (2002). Gjendja e sotme në studimet tona bregdetare dhe disa detyra për të ardhmen [Today's situation in our coastal studies and some tasks for the future]. Studime gjeografike, (14), 137-147.

Boçi, S. (2018). Probleme të bregdetit të Adriatikut Shqiptar [Problems of the Albanian Adriatic coast] (manuscript).

Pano, N. (1984). Hidrologjia e Shqiperise [Hydrology of Albania]. Akademia e Shkencave e te Shqiperise, Instituti Hidrometeorologjik, Tirana, Albania. 
Pano, N. (1992). Dinamica del litorale albanese (sintesi delle conoscenze). In Atti del $10^{\circ}$ Congresso della Associazione Italiana di Oceanologia e Limnologia (pp. 3-18), Genova, Italy. G. Lang Publishers. http://www.aiol.info/wp-content/ uploads/ATTI_10_CONGRESSO_AIOL_1_2.pdf?fbclid=Iw AR23qJt6fcWRYlkvBSM8E1FaQJTrLFn7VMLjAOZDa69TzBTnCIVla5h5ma8

Paskoff, R. (1985). Les cotes d'Albanie. Aspects geomorphologiques. Bulletin de l'Association de Geographie, 2, 77-83. https://doi.org/10.3406/bagf.1985.1284

Shuisky, Y. (1985). Albania. In E. C. F. Bird \& M. L. Schwartz (Eds.), The world's coastline (pp. 43-444). Van Nostrand Reinhold Company, New York, USA.

Simeoni, U., Pano, N., \& Ciavola, P. (1997). The coastline of Albania: morphology, evolution and coastal management issues. Bulletin de l'Institut oceanographique, Monaco, (18). 